\title{
The Assessment of Environmental Risks and the Regulation of Process and Production Methods (PPMs) in International Trade Law
}

\author{
Andreas R Ziegler and David Sifonios
}

\subsection{Introduction}

International attention to environmental issues has grown substantially during the past four decades, as the considerable development of international environmental law since the 1970s demonstrates. Global environmental concerns have emerged, such as the need to mitigate climate change, to protect biodiversity and endangered species, and to achieve sustainable development. The international community has realized that it must act to address important global environmental risks.

Implementation of environmental policies requires the adoption not just of environmental law but, in some circumstances, the adoption of trade regulations. For instance, to achieve environmental objectives, states may seek to control the physical properties of products sold in their internal markets, and thus the physical impact related to the use of such products, such as the pollution caused by the use of a car (product standards). However, in certain cases, the main environmental impact of a product is not caused by its consumption or by its use, but rather by its production, such as the pollution caused by the manufacturing of a car. States may thus be willing to adopt environmental standards addressing the environmental impact caused by the 'process and production methods' (PPMs) of a particular good. When production occurs abroad, the only possibility for a state to address the environmental impact caused by production is to condition the possibility to import products into its market on the requirement that foreign producers comply with certain PPM standards. Trade restrictions based on PPMs may take the form of an import prohibition of certain products (eg, tuna caught in a manner harmful to dolphins, ${ }^{1}$ shrimps harvested by using methods that kill sea

1 See, eg, GATT, United States-Restrictions on Imports of Tuna (3 September 1991) DS21/R (unadopted) (US-Tuna I).

The Assessment of Environmental Risks and the Regulation of Process and Production Methods (PPMs) in International Trade Law Andreas R. Ziegler and David Sifonios (C) Andreas R. Ziegler and David Sifonios, 2017. Published 2017 by Oxford University Press. 
turtles, ${ }^{2}$ or seals killed in a cruel way ${ }^{3}$ ). They can also represent a tax on imported products based on the environmental costs caused by the production of these products, such as the pollution emitted during their manufacturing process (eg, greenhouse gases emissions).

Traditionally, PPM trade restrictions have been viewed with suspicion under international trade rules, resulting in important tensions between environmental protection and trade liberalization. ${ }^{4}$ PPM measures may seem to be a useful or necessary tool to address the risks posed by pollution or environmental harm caused by the production of certain products. At the same time, the imposition of PPM measures increases barriers to trade, questions the right of the exporting country to choose its environmental policies, and may give rise to important compliance difficulties for certain developing countries. ${ }^{5}$ This chapter examines the evolution of the case law relating to the legality of PPM measures and how the respective visions of the future on which the 1947 General Agreement on Tariffs and Trade (GATT) and the 1995 World Trade Organization (WTO) agreements are based have influenced the interpretation of international trade rules applicable to such measures.

\subsection{The PPM Debate}

A detailed discussion of the intense controversies regarding the legality of PPM measures under multilateral trade rules goes beyond the scope of this chapter. ${ }^{6}$ In brief, as far as WTO law is concerned, the debate has focused on two main aspects. The first is whether differences in PPMs might be relevant in the examination of whether two products are 'like' in the sense of the non-discrimination obligations contained in Articles I and III of the GATT. Article I, the Most-Favoured-Nation

2 See WTO, United States-Import Prohibition of Certain Shrimp and Shrimp Products (15 May 1998) WT/DS58/R (US-Shrimp I); WTO, United States—Import Prohibition of Certain Shrimp and Shrimp Products (12 October 1998) WT/DS58/AB/R (US_Shrimp It).

3 See WTO, European Communities-Measures Prohibiting the Importation and Marketing of Seal Products (18 June 2014) WT/DS400/R, WT/DS401/R (EC-Seal Products).

4 As it has been described elsewhere, the word 'protection' 'warms the hearts of environmentalists but sends chills down the spines of free traders'. See D Esty, Greening the GATT (Institute for International Economics 1994) 36.

5 See, eg, the view expressed by developing countries which are part of the Group of 77 South Summit, 'Declaration of the South Summit', 12-14 April 2000, para 21. 'While recognizing the value of environmental protection, labour standards ... and protection of all universally recognized human rights and fundamental freedoms, ... we reject all attempts to use these issues as conditionalities for restricting market access or aid and technology flows to developing countries.'

6 For a discussion of the PPM debate, see, eg, S Charnovitz, "The Law of Environmental "PPMs" in the WTO: Debunking the Myth of Illegality' (1998) 27 Yale Journal of International Law 59; RE Hudec, 'The Product-Process Distinction in GATT/WTO Jurisprudence' in M Bronckers and R Quick (eds), New Directions in International Economic Law: Essays in Honour of John H. Jackson (Kluwer Law International 2000) 187 ff; R Howse and D Regan, 'The Product/Process Distinction-An Illusory Basis for Disciplining "Unilateralism” in Trade Policy' (2000) 11 European Journal of International Law 249; CR Conrad, Processes and Production Methods (PPMs) in WTO: Interfacing Trade and Social Goals (Cambridge University Press 2011). See also D Sifonios, Environmental Process and Production Methods (PPMs) in WTO Law (PhD thesis forthcoming). 
clause, essentially provides that any advantage granted by an importing member to any imported product originating in any other member must be accorded to like imported products originating in all other members. Article III, which articulates the National Treatment obligation, provides that imported products must not be granted less favourable treatment than like domestic products. Thus, if two products can be considered as unlike on the basis of their respective PPMs, the MostFavoured-Nation and National Treatment obligations will not apply.

The second main debate concerns the issue of whether PPM measures, which otherwise violate Articles I and III can nonetheless be justified under the general exceptions provision of Article XX of the GATT and thus be considered to comply with the GATT. $^{7}$ In this context, various arguments have been invoked to justify a prohibition of PPM measures under the GATT. On the one hand, it has been claimed that PPM measures conflict with the principle of state sovereignty. Some have argued that PPM measures are extraterritorial, since they apply to conduct occurring abroad ${ }^{8}$ and that they constitute interference in the internal affairs of the exporting country. ${ }^{9}$ PPM measures have been particularly strongly criticized when developed states have adopted or considered adopting PPM measures against developing countries, which do not necessarily have the same environmental priorities or the same responsibilities as developed nations in the particular environmental threat in issue. ${ }^{10}$ This is particularly apparent in the climate change context.

On the other hand, it has also been claimed that PPM measures could represent a threat to the basic objectives of the multilateral trading system. One of the main achievements of the GATT has been the significant reduction of tariff levels applicable to manufactured goods, from an average of forty per cent in 1947, to

7 The PPM controversy also includes debates concerning the applicability and consequences of the rules of the TBT and SPS Agreements for PPM measures. See, eg, Conrad, Processes and Production Methods (PPMs) in WTO (n 6) $374 \mathrm{ff}$.

8 See TJ Schoenbaum, 'International Trade and Protection of the Environment: The Continuing Search for Reconciliation' (1997) 91 American Journal of International Law 268, 279 f; B Jansen and M Lugard, 'Some Considerations on Trade Barriers Erected for Non-Economic Reasons and WTO Obligations' (1999) 2 Journal of International Environmental Law 530, 533 ff; K Bagwell, P Mavroidis, and RW Staiger, 'It's a Question of Market Access' (2002) 96 American Journal of International Law 56, 76; H Horn and P Mavroidis, 'The Permissible Reach of National Environmental Policies' (2008) 42 Journal of International Environmental Law 1107, 1125 et passim. See also GATT, United StatesRestrictions on Imports of Tuna (16 June 1994) DS29/R (unadopted) (US-Tuna II) para 5.17. For a contrary position, see A Nollkaemper, 'Rethinking States' Rights to Promote Extra-Territorial Environmental Values' in F Weiss et al (eds), International Economic Law with a Human Face (Kluwer Law International 1998) 189; Howse and Regan, 'The Product/Process Distinction' (n 6) 274 and 278; E Vranes, Trade and the Environment (OUP 2009) 166.

9 A majority of commentators have concluded that in principle trade restrictions do not violate the principle of non-intervention, except in very exceptional circumstances, such as when the producing country is largely dependent on exports. See A Appleton, Environmental Labelling Programmes (The Graduate Institute 1997) 83; D Luff, Le droit de l'Organisation mondiale du commerce (Bruylant and LGDJ 2004) 158 f; BJ Condon, Environmental Sovereignty and the WTO (Transnational Publishers 2006) 253.

10 See J Jackson, 'World Trade Rules and Environmental Policies: Congruence or Conflict?' (1992) 49 Washington and Lee Law Review 1227, 1230; F Bierman, 'The Rising Tide of Green Unilateralism in World Trade Law' (2001) 35 Journal of World Trade 421, 433; Esty, Greening the GATT (n 4) 184. See also the Group of 77 South Summit, 'Declaration of the South Summit' (n5) para 21. 
around three per cent for industrialized countries after the Uruguay Round, which concluded in $1995 .{ }^{11}$ As a result, the attention has gradually shifted to non-tariff barriers, such as domestic regulations in the field of safety, health, consumer, or environmental protection. Such regulations currently represent the principal barriers to trade and the main source of protectionism. ${ }^{12}$ This is because foreign producers may have difficulty in meeting the standards set by the importing country and because even prima facie non-discriminatory measures can be designed so as to burden imports or products originating from a particular country more heavily, thereby resulting in de facto discrimination. PPM measures represent a form of technical barrier to trade and some fear that allowing states to require the adoption of specific environmental practices in the exporting country would be like opening a 'Pandora's box' and would represent a 'slippery slope', by which trade rules would actually allow the adoption of regulations that represent significant obstacles to trade. ${ }^{13}$ Based on these considerations, it has been argued by some that PPM measures should be prohibited under trade rules. ${ }^{14}$

Yet, the prohibition of PPM measures could, in practice, result in the inability of states to address international and global environmental problems. When the source of environmental harm is located abroad, the most efficient measures are those which allow intervention at the source (first-best solutions). ${ }^{15}$ This can only be achieved through cooperation between the different states concerned. However, as demonstrated by the international climate change negotiations, effective international cooperation to address global environmental problems has often proved to be particularly difficult to achieve. In the absence of this cooperation, trade measures are usually the only possible means by which a state may intervene (second-best solutions), ${ }^{16}$ in particular to sanction non-compliance with international obligations or free riding by other states which refuse to participate in international efforts. ${ }^{17}$ If such sanctions are prohibited under trade rules, the dominant strategy for states remains non-cooperation, which leads to a classical and economically suboptimal prisoner's dilemma situation. Such cooperation failure may then lead to the 'tragedy of the commons', ${ }^{18}$ ie degradation or destruction of global ecosystems

11 See MJ Trebilcock and R Howse, 'Trade Liberalization and Regulatory Diversity: Reconciling Competitive Markets with Competitive Politics' (1998) 6 European Journal of Law and Economics 5, 6; D Carreau and P Juillard, Droit international économique (3rd edn, Dalloz 2007) $185 \mathrm{f}$.

12 See Carreau and Juillard, ibid, 187.

13 See J Bhagwati, In Defense of Globalisation (OUP 2004) 154 f; Jackson, 'World Trade Rules and Environmental Policies' (n 10) 1241 f. See also GATT Secretariat, 'Trade and the Environment' in International Trade 1990-1991, Vol 1 (Geneva 1992). 'If the door were opened to use trade policies unilaterally to offset the competitiveness effects of different environmental standards, or to attempt to force other countries to adopt domestically favoured practices and policies, the trading system would start down a very slippery slope.'

14 See eg GATT Secretariat, ibid. This document explains that PPM measures should be excluded because otherwise it 'would invite a flood of import restrictions'.

15 See, eg, TA Pugel, International Economics (Irwin McGraw-Hill 2009) 272.

16 ibid, 281.

17 See, eg, S Barrett, Environment and Statecraft: The Strategy of Environmental Treaty-Making (OUP 2007) 314 et passim.

18 See the famous article of G Hardin, 'The Tragedy of the Commons' (1968) 162 Science 1243. 
or shared resources. Thus, in brief, a prohibition of PPM measures may reinforce the risks of states' cooperation failures in the field of international environmental protection and the risks of global environmental crises.

Hence, while some have objected to the legality of PPM measures under the GATT for trade and development reasons, others have opposed the prohibition of such measures under WTO law based on environmental grounds.

\subsection{Competing Imageries of the Future}

The debate on the legality of PPM measures can be placed within a broader context in which interests relating to environmental protection, development, and trade co-exist. The PPM debate may be viewed as one involving competing opinions as to the nature, scope, and scale of the different risks at stake and as a debate as to which interests should ultimately prevail. These different views are influenced in part by competing imageries of the future.

A first image is that of economic prosperity. Developing countries, for example, may be seen as imagining a future in which they have achieved economic development, eradicated poverty, and guaranteed their citizens' basic needs, such as education or healthcare. Developing countries may have great difficulty in complying with environmental standards adopted by developed states because of the generated additional costs, or simply because of the lack of means to verify compliance with PPM requirements. The use of a particular production method usually does not influence the physical properties of a product (so-called non-product-related PPMs). Therefore, producing countries have to establish verification mechanisms to certify compliance with the prescribed PPM standards. Developing countries tend to see the means and costs necessary to implement such certification procedures as important obstacles to trade, or at least as interference with their own social and economic preferences. ${ }^{19}$ As a result, they often consider the adoption of PPM measures by importing countries as entailing risks for their economic development and the achievement of their vision of a prosper future.

A similar view may be taken by those who favour free trade. As far as international trade is concerned, free traders basically imagine a world in which the absence of trade barriers enables states to maximize their comparative advantages and wealth. ${ }^{20}$ This increased wealth should then eventually provide states with the additional means necessary to tackle environmental problems. On this view, state regulations, including for non-economic purposes, are seen as a risk or threat to the achievement of this objective, insofar as they represent forms of technical barriers to trade, which tend to jeopardize trade liberalization.

Thus, both free traders and developing countries which oppose the use of PPM measures agree on the view that priority should be given to trade and economic

19 See Biermann, 'The Rising Tide of Green Unilateralism in World Trade Law' (n 10) 433.

20 See, eg, J Jackson, The World Trading System (The MIT Press 1997) 237. 
development, in order to achieve a prosperous economic future. They argue that regulations, which put the pursuit of that future at risk, such as environmental regulations, should be eliminated. Environmental problems will eventually be addressed in this economically prosperous future, with the additional means that will be at states' disposal when this future is achieved.

The contrasting image, relied on by proponents of the use of PPM measures, tends to imagine a future in which the environment has been preserved, both at the regional and global levels. Proponents of this vision recognize that failure to address global environmental problems today may eventually lead to catastrophic environmental futures. These risks may concern the international community as a whole, at least when global environmental risks are concerned (climate change, biodiversity, species extinction, overexploitation of common fish stocks, etc), although agreement on the nature, intensity, and extent of these risks or on the need and means by which to address them may not be uniform. ${ }^{21}$ In any event, the means to achieve this 'green' future is considered to be through environmental regulation aimed, among other things, at correcting existing market failures. ${ }^{22}$ On this view, the expansion of international trade is perceived with suspicion. First, increased production and transport may exacerbate environmental stress. Second, it is sometimes feared that international trade rules, if unconstrained, could favour environmentally unsound production practices from 'pollution havens'. ${ }^{23}$ Environmental trade measures are thus perceived as a way to reduce these risks and to achieve a 'green' future.

Thus, depending on the particular vision of the future adhered to, perceptions of the relative importance of the environmental, trade, and development risks at stake differ. The issue of the legality of PPM measures encapsulates the conflict between those who consider that too little constraint of such measures could jeopardize the functioning of the multilateral trading system and those who consider that overly stringent focus on trade disciplines could prevent states from achieving effective international environmental protection, leading to global environmental

21 For instance, the United States and the European Communities did not agree, in the WTO EC-Hormone case (WTO, European Communities-Measures Concerning Meat and Meat Products [Hormones] (13 February 1998) WT/DS26/AB/R, WT/DS48/AB/R (EC-Hormone)), on whether hormone-treated beef represented an externality and whether that externality had to be internalized. This dispute concerned two developed countries and mainly concerned health issues. Yet, this case is interesting insofar as it showed, as Pauwelyn has pointed out, that the fundamental issue in this dispute was whether there was a need for the government to intervene at all or whether the market could deal with the problem. J Pauwelyn, 'Recent Books on Trade and Environment: GATT Phantoms Still Haunt the WTO’ (2004) 15 European Journal of International Law 575, 579.

22 On the economic justification for state intervention in cases of market failures see, eg, JE Stiglitz and CE Walsh, Economics (4th edn, WW Norton 2006) 252.

23 See Schoenbaum, 'International Trade and Protection of the Environment' (n 8) 288-89; AL Strauss, 'From GATTzilla to the Green Giant: Winning the Environmental Battle for the Soul of the World Trade Organization' (1998) 19 University of Pennsylvania Journal of International Economic Law 769, 808; M Trebilcock and R Howse, The Regulation of International Trade (3rd edn, Routledge 2005) 661. 
degradation. Section 12.4 examines how these different visions of the future have been visible in GATT and WTO case law.

\subsection{Evolutions of the GATT and WTO Case Law on PPM Measures}

One of the most notable disputes relating to trade and the environment, which was examined by two GATT 1947 panels at the beginning of the 1990s, concerned a US embargo on Mexican tuna that was caught in a manner that resulted in the incidental killings of dolphins. ${ }^{24}$ The measure adopted by the United States also provided for a secondary embargo applying to all third countries that did not prohibit imports of tuna from Mexico. This secondary embargo was challenged under the GATT by the European Communities. ${ }^{25}$ In 1998, after the creation of the WTO, a similar dispute arose when the United States prohibited the importation of shrimp caught in a manner which harmed sea turtles. In effect, the US legislation required shrimp-producing countries that exported shrimp products to the United States to adopt regulations mandating the use of fishing methods that did not harm sea turtles. This measure was challenged before the WTO by four Asian shrimp-exporting countries. ${ }^{26}$ These different cases all concerned measures which prescribed the use, in the exporting country, of particular PPMs (in both cases relating to fishing methods), which did not physically affect the final product, giving rise to an intense debate as to the legality of the measures. ${ }^{27}$

The panels in these cases examined whether the PPM measures concerned could comply with Article XX of the GATT, which sets out a list of public policy goals which may be invoked to justify a measure that infringes GATT obligations. However, environmental protection is not one of the public policy goals listed. For this reason, environmental concerns have, in general, been examined in dispute settlement practice under subparagraph (b), which applies to the protection of human, animal, or plant life or health, and subparagraph $(\mathrm{g})$, which concerns the conservation of exhaustible natural resources. Since Article XX of the GATT does not explicitly refer to PPM measures, and because of the omission of reference to environmental goals in this provision, the legal regime applicable to environmental PPM measures depends in large part on how Article XX of the GATT is interpreted in the case law; and this depends on competing interpretations of the basic concepts underlying multilateral trade rules and competing visions and imageries of the future these trade rules are designed to achieve and serve.

${ }^{24}$ See US-Tuna I; US_Tuna II. $\quad{ }^{25}$ See US-Tuna II.

26 See US-Shrimp-I; US-Shrimp-II.

27 See, eg, Charnovitz, 'The Law of Environmental "PPMs" in the WTO' (n 6); Hudec, 'The Product-Process Distinction in GATT/WTO Jurisprudence' (n 6); Howse and Regan, 'The Product/ Process Distinction' (n 6); J Jackson, 'Comments on Shrimp/Turtle and the Product/Process Distinction' (2000) 11 European Journal of International Law 303. 


\subsubsection{First phase: the GATT 1947 and the Tuna-Dolphin cases}

The reports in the Tuna-Dolphin cases were not adopted by the contracting parties, because of the opposition of the United States. (Under the GATT 1947, positive consensus was required for the adoption of a panel report.) These reports thus have no legal force as such. ${ }^{28}$ However, they have had indirect influence in that they have been quoted by subsequent reports ${ }^{29}$ and have given rise to considerable debates in academic writings. ${ }^{30}$ In the Tuna-Dolphin reports, the panels expressed the view that if the GATT allowed an importing member to adopt trade measures to force other members to change their environmental policies within their own jurisdiction, the GATT could 'no longer serve as a multilateral framework for trade among contracting parties' ${ }^{31}$ One of the main concerns was that accepting such a rule could mean that the GATT would provide legal certainty only between members with identical internal regulations. ${ }^{32}$ The Shrimp-Turtle panel was similarly concerned with conflicting requirements between several importing countries applying to the same subject for the same exporting countries, making it impossible for the states concerned to comply with all of these requirements at the same time. ${ }^{33}$ The panel emphatically stated that allowing such measures could 'rapidly lead to the end of the WTO multilateral trading system'. ${ }^{34}$

In an effort to exclude the perceived risks for the multilateral trading system arising from the use of PPM measures, the panel reports in both cases suggested that the drastic solution of prohibiting PPM measures should be applied. There was no assessment of the environmental risks at stake in these cases, which seemed to be irrelevant in the view of the panels.

The prohibition of PPM measures based on the 'risks for the multilateral trading system' has been heavily criticized in academic writings which have, for example, referred to 'fabricated illogical reasons' as to why Article XX of the GATT could not be used to justify unilateral PPM measures. ${ }^{35}$ It has been pointed out that the panels' attitude could be counterproductive and could actually threaten the multilateral trading system by triggering concerns as to the system's hostile attitude towards broader public interests. ${ }^{36}$ Indeed, precisely such hostile reactions did occur after the release of the Tuna-Dolphin reports. At that time, free-trade

28 See WTO Japan - Taxes on Alcoholic Beverages (1 November 1996) WT/DS8/AB/R, WT/DS10/ AB/R, WT/DS11/AB/R, 15 (Japan-Alcohol H). The Appellate Body, however, stated that unadopted reports could provide 'useful guidance' Japan-Alcohol $\#, 16$.

29 See, eg, US_Shrimp I, paras 7.16, 7.36, 7.46; WTO, European Communities-Measures Affecting Asbestos and Asbestos-Containing Products (5 April 2001) WT/DS135/R, paras 8.37, 8.167, 8.272; Panel Report, United States_Measures Affecting the Cross-Border Supply of Gambling and Betting Services (20 April 2005) WT/DS285/R, para 6.526.

30 See, eg, Charnovitz, 'The Law of Environmental "PPMs" in the WTO' (n 6); Hudec, 'The Product-Process Distinction in GATT/WTO Jurisprudence' (n 6); Howse and Regan, 'The Product/ Process Distinction' (n 6); Jackson, The World Trading System (n 20); Conrad, Processes and Production Methods (PPMs) in WTO (n 6).

31 US - Tuna II, para 5.26; US_Tuna I, para 5.28. $\quad 32$ See US_Tuna I, para 5.27.

33 See US_ShrimpI, para 7.45. $\quad 34$ ibid.

35 See S Charnovitz, 'The WTO's Environmental Progress' (2007) 10 Journal of International Environmental Law 685, 696.

36 ibid. 
critics used the expression of 'GATTzilla' to describe what was perceived as a trading system which threatened environmental protection and state sovereignty. ${ }^{37}$ In the eyes of these critics, the GATT unduly restricted GATT members' regulatory autonomy and entailed risks of preventing governmental action to address global environmental issues. ${ }^{38}$ Important risks of cooperation failures could ensue, leading to international inaction in the field of environmental protection, because the imports of products produced by non-cooperating states, using environmentally harmful PPMs, could not be restricted under international trade law rules. So was the argument.

\subsubsection{Second phase: the WTO and the Shrimp-Turtle Appellate Body Report}

In 1998, only a few years after the Tuna-Dolphin cases, and in the first years of the newly created WTO, the issue of the legality of PPM measures under multilateral trade rules was brought again before the WTO in the Shrimp-Turtle case. The Appellate Body adopted a different approach from that of the Tuna-Dolphin and Shrimp-Turtle panels. It held that conditioning access to a member's domestic market on whether exporting members comply with a policy unilaterally prescribed by the importing member might be a 'common aspect' of measures falling within the scope of one of subparagraphs of Article XX of the GATT. ${ }^{39}$ Implicitly, the Appellate Body rejected the argument that a perceived 'threat' to the multilateral trading system was an element that was relevant to the interpretation of the GATT. This finding had far-reaching consequences for PPM measures, since it implied that their 'unilateral' or 'coercive' character would not, of itself, render such measures incapable of justification.

In this dispute, the United States initially lost on appeal under Article XX of the GATT, in particular because of the lack of flexibility in the methods that could be used by exporting countries to protect sea turtles during shrimp trawling, the violation of due process requirements relating to the transparency of the certification procedures, and because the United States had negotiated an international

37 See Esty, Greening the GATT (n 4) 35 ff. Critics of the Tuna-Dolphin reports invoking state sovereignty have referred in particular to the right of states to choose the conditions upon which products may be sold on their internal market. It should be pointed out that GATT members which opposed the use of PPM measures have also invoked state sovereignty, in particular the principle of permanent sovereignty over natural resources. In their view, this principle means that importing states cannot impose on imported products PPM standards that conflict with the right of exporting countries to exploit their natural resources as they choose to. This issue is part of the wider debate about whether PPM measures are extraterritorial in a legal sense and whether the customary international law rules on prescriptive jurisdiction restrict the ability of states to adopt PPM measures. See, eg, Sifonios, Environmental Process and Production Methods (PPMs) in WTO Law (n 6).

Reactions to the reports in the US - Shrimp case were less critical. See, eg, Charnovitz, 'The WTO's Environmental Progress' (n 35) 696. He states that through its US-Shrimp report, among other reports, the Appellate Body 'sent a signal to the public that the era of runaway panels on environmental matters was over'.

38 See, eg, Strauss, 'From GATTzilla to the Green Giant' (n 23) 771.

39 US-Shrimp $\mathrm{H}_{2}$ para 121. 
agreement on sea turtle protection with some of its trading partners prior to the imposition of the import ban, but not with the complainants. ${ }^{40}$ In the view of the Appellate Body these different elements constituted 'arbitrary or unjustified discrimination' between the exporting countries concerned, in the sense of the chapeau of Article XX of the GATT. Eventually, three years after the initial case, after the United States had made similar negotiation efforts with the complaining members and had adopted a more flexible measure which allowed the use of sea turtle protection methods that were comparable in effectiveness, the Appellate Body upheld the contested measure. ${ }^{41}$

The Shrimp-Turtle Appellate Body's report thus applied a much more subtle and balanced approach to the respective risks of stringent or lax trade rules for the functioning of the multilateral trading system and the ability of states to take environmental trade measures: PPM measures are not GATT illegal per se, but the different conditions of Article XX of the GATT discipline the ability of WTO members to enact such measures. ${ }^{42}$

\subsubsection{Subsequent evolutions of case law}

The reports in the Shrimp-Turtle case have shown that PPM measures were not illegal per se in WTO law. However, the precise conditions under which such measures are justifiable, and the way competing interests and risks should be taken into account in the application of the relevant provisions, have often remained unclear since this dispute. Nevertheless, the case law relating to Articles III and XX of the GATT has continued to evolve. In particular, several cases have concerned the relation between international trade rules and non-economic objectives, such as health, ${ }^{43}$ environmental protection, ${ }^{44}$ or public morality. ${ }^{45}$ These cases have provided certain clarifications on the legal regime applicable to PPM measures. For the limited purpose of this chapter, however, it is not necessary to explain the details of this complex case law. Rather, certain specific aspects will be highlighted in the following sections.

40 ibid, paras 161-76.

41 See WTO, United States-Import Prohibition of Certain Shrimp and Shrimp Products, Recourse to Article 21.5 of the DSU by Malaysia (22 October 2001) WT/DS58/AB/RW, (US-Shrimp 21.5).

42 The Appellate Body held in its US - Shrimp $H$ report that the importing country must in particular show that a 'sufficient nexus' exists with the environmental situation at stake; US - Shrimp H, para 133. It has to establish that it has conducted 'across-the-board' international negotiations in order to conclude an international environmental agreement; US - Shrimp H, para 166. It must also ensure that its measure is flexible enough to take into account differing conditions that may occur in the importing and exporting countries; US_Shrimp H, para 161.

43 See WTO, European Communities-Measures Affecting Asbestos and Asbestos-Containing Products (5 April 2001) WT/DS135/AB/R (EC-Asbestos); WTO, Brazil-Measures Affecting Imports of Retreaded Tyres (17 December 2007) WT/DS332/AB/R (Brazil_Tyres).

${ }^{44}$ See WTO, United States-Measures Concerning the Importation, Marketing and Sale of Tuna and Tuna Products (13 June 2012) WT/DS381/AB/R. This case still concerned the dispute between the United States and Mexico on the legality of the 'dolphin-safe' label on tuna products. This second dispute between the two countries, after the 1991 GATT Panel report, was examined under the rules of the Agreement on Technical Barriers to Trade.

45 See EC-Seal Products. The case concerned an embargo of the European Union on seals and seal products, justified on the basis of the cruelty of the way seals were killed. 


\subsection{The Evolution of Case Law in the Light of Imageries of the Future}

When the WTO was created in 1995, the GATT 1947 was integrated into the WTO agreements without changes to its text. In other words, the evolution of the case law regarding the legality of PPM measures, described in section12.4, has not been based on any changes in the relevant provisions of the GATT. It can be argued that it is instead a change in the vision of the future underlying the multilateral trading system that explains this evolution, at least in part.

The GATT 1947 indicates in its Preamble that this agreement has the objective of developing the 'full use of the resources of the world'. At the end of the 1940s, the focus of the GATT signatories was clearly on developing international trade, not on the linkage between trade and environmental protection. The GATT was thus founded on the vision of a 'free-trade future' described in section 12.3 above. In a way, the 1991 and 1994 Tuna-Dolphin reports, even though they were delivered more than forty years later, still illustrated this conception in which the GATT was seen in complete isolation from other international concerns, and in which the reduction of obstacles to trade was seen as the prevailing objective of the world trading system. In such a view, there was little room for environmental interests, at least when they entailed the imposition of non-consensual trade restrictions. In order to eliminate the risks that trade measures unduly restricted trade liberalization, GATT rules were interpreted as prohibiting PPM measures, without consideration of the risks of catastrophic environmental futures entailed by such an approach.

As mentioned, when the WTO agreements were adopted in 1995, the text of the GATT 1947 was not modified. However, the Preamble of the Marrakesh Agreement establishing the WTO (WTO Agreement) introduced an important concept, by stating that one of the objectives of the multilateral trading system was to allow the 'optimal use of the world's resources in accordance with the objective of sustainable development seeking both to protect and preserve the environment and enhance the means for doing so in a manner consistent with their respective needs and concerns at different levels of economic development'. ${ }^{46}$

The Appellate Body held in the Shrimp - Turtle case that the objective of sustainable development has to be taken into account in the interpretation of WTO law. In

46 See the Preamble of the Marrakesh Agreement:

The Parties to this Agreement, recognizing that their relations in the field of trade and economic endeavour should be conducted with a view to raising standards of living, ensuring full employment and a large and steadily growing volume of real income and effective demand, and expanding the production of and trade in goods and services, while allowing for the optimal use of the world's resources in accordance with the objective of sustainable development, seeking both to protect and preserve the environment and to enhance the means for doing so in a manner consistent with their respective needs and concerns at different levels of economic development (...)

Marrakesh Agreement Establishing the World Trade Organization (adopted 15 April 1994, entered into force 1 January 1995) 1867 UNTS 154, Preamble (WTO Agreement). 
its view, sustainable development 'must add colour, texture and shading' to its interpretation of WTO agreements. ${ }^{47}$ Yet, the WTO agreements contain no definition of sustainable development and the Appellate Body has not provided any details as to what sustainable development actually means, nor has it explicitly explained how it could add 'colour, texture and shading' to the interpretation of these agreements. Furthermore, there is no uniform definition of sustainable development in international law or any consensus on how to give it concrete effect in individual cases, ${ }^{48}$ which could guide the treaty interpreter as to the way the principle of sustainable development could influence in practical terms the interpretation of the GATT provisions. It is, however, generally acknowledged in the academic literature and relevant legal documents that one of the most important aspects of sustainable development is the principle of integration, which means that sustainable development should achieve the integration of environmental protection and economic development. ${ }^{49}$ Another important element is the principle of inter-generational equity, which states that 'sustainable development is development that meets the needs of the present generation without compromising the ability of future generations to meet their own needs'..$^{50}$

Despite the vague character of the principle of sustainable development, it could be argued that through this principle, WTO members have contemplated a very general common vision of the future. As the terms used in the Preamble of the WTO Agreement show, such vision may be viewed as one which seeks to reconcile the two competing imageries of the future that underlie the PPM debate. By referring to the objective to 'protect and preserve the environment and enhance the means for doing so', the WTO Agreement Preamble refers, at the same time, to a vision of a future in which the global environment has been preserved and a vision of a future in which international trade has, through economic prosperity, brought additional means to protect the environment. The term 'optimal' use of the world's resources also indicates the need to find a balance between competing risks and interests in order to develop international trade without harming the environment in the long run. In brief, the achievement of this common vision of the future, represented by sustainable development, requires that the treaty interpreter achieve some form of trade-off between competing risks (risk/risk trade-offs).

Several concrete aspects of the Appellate Body's case law may in practice be interpreted as attempts to take into consideration competing risks; ie, to achieve such risk/ risk trade-offs. On the one hand, trade liberalization and the reduction of obstacles to trade remain one of the most important bases of the GATT. It could be argued that it has directly influenced the Appellate Body's interpretation of the National Treatment obligation, in particular in relation to the concept of 'like products'. The Appellate

47 US_Shrimp H, para 153.

48 See P Birnie, A Boyle, and C Redgwell, International Law and the Environment (3rd edn, OUP 2009) 125 .

49 See United Nations Conference on Environment and Development, 'Declaration of the United Nations Conference on Environment and Development' (3-4 June 1992) A/CONF.151/26 (Vol I), principle 4 (Rio Declaration). See also Birnie et al, ibid, 116.

50 World Commission on Environment and Development, Our Common Future (OUP 1987) 43. 
Body has endorsed an economic definition of this concept, which focuses on the competitive relationship between products in the marketplace. ${ }^{51}$ It has thus rejected the view that two products could be considered to be unlike simply because they have, say, different environmental impacts, ${ }^{52}$ at least as long as such impact does not influence consumers' tastes and habits and thus the competitive relationship between the products concerned.

On the other hand, environmental interests are taken into account through the application of Article XX of the GATT. This provision was interpreted narrowly under the GATT 1947.53 As a result, compliance with the conditions of Article XX, in particular its necessity test, were particularly difficult to achieve. ${ }^{54}$ By contrast, several aspects of the Appellate Body report in the Shrimp-Turtle case show a much more balanced and flexible approach. First, as indicated above, the Appellate Body has confirmed that a PPM measure could comply with the GATT, if certain conditions are met. ${ }^{55}$ In brief, this case has shown that environmental risks (in this case, the risk of extinction of an endangered species) can justify a restrictive trade measure, provided that the regulating member minimizes unnecessary trade impacts.

Beside this general aspect, which may be viewed as a form of integration of trade and environmental interests, a second specific example could be mentioned. In its report, the Appellate Body held that turtles were 'exhaustible natural resources' in the sense of Article XX $(\mathrm{g})$ of the GATT. ${ }^{56}$ Complainants in this case had argued that this exception had been construed by the drafters of the GATT as applying to non-living natural resources such as minerals and not to living resources. The Appellate Body applied what has been referred to as an evolutionary interpretation $^{57}$ to include non-living resources in the scope of Article XX $(\mathrm{g})$ of the GATT. In its analysis, the Appellate Body explicitly referred to the objective of sustainable development mentioned in the Preamble of the WTO Agreement as one of the bases of its interpretation. ${ }^{58}$

Furthermore, the Appellate Body has interpreted the conditions of Article XX of the GATT in a more flexible manner than that which prevailed under the GATT

51 See Japan-Alcohol H, 16; EC-Asbestos, para 98.

52 See the rejection of the 'aims-and-effects' definition of 'like' products (under which two products are alike if the regulatory measure distinguishing between them pursues protectionist intent and results in protectionist effects) in the Japan-Alcohol case. WTO, Japan-Taxes on Alcoholic Bevereges (11 July 1996) WT/DS8/R, WT/DS10/R, WT/DS11/R (Japan-Alcohol $¥)$ paras 6.16-6.18 Japan-Alcohol $H, 16$ (endorsing the economic definition of the concept of like products).

53 See, eg, US - Tuna I, para 5.22.

54 See, eg, A Appleton, 'GATT Article XX's Chapeau: A Disguised "Necessary" Test?: The WTO Appellate Body's Ruling in United States-Standards for Reformulated and Conventional Gasoline' (1997) 6 Review of European Community and International Environmental Law 131, 136.

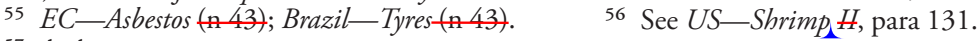

57 ibid, para 130.

58 ibid, para 129. In this paragraph, the Appellate Body recalled that even though the words of Article XX (g) of the GATT were crafted fifty years earlier, they had to be read by the treaty interpreter in the light of contemporary concerns of the community of nations about protection and conservation of the environment. It added that the signatories of the WTO Agreement were fully aware of the importance and legitimacy of environmental protection and that the Preamble of this agreement explicitly acknowledged the objective of sustainable development. 
1947 practice. For example, it has interpreted the necessity test applicable in particular in the context of subparagraph (b) as a 'weighing and balancing' test, by which the treaty interpreter takes into account the importance of the values and interests at stake, the contribution of the measure to the achievement of the goal, and its trade-restrictiveness. ${ }^{59}$ Through this interpretation, environmental risks and trade risks may each be considered, respectively, through the first and third criteria. In the view of the Appellate Body, the more important these non-trade interests are, the easier it would be to accept them as 'necessary'. ${ }^{60}$ This shows that an assessment of the environmental risks at issue should be carried out to enable a proper application of this 'weighing and balancing' test.

In the same vein, the Appellate Body has held that the conditions of the chapeau mean that the treaty interpreter needs to find a 'line of equilibrium' between the substantive obligations of the GATT and the general exceptions provision. ${ }^{61}$ The substantive obligations are meant to allow the achievement of the objective of trade liberalization. At the same time, the need to find a line of equilibrium between such obligations and the general exceptions provision, which introduces non-economic concerns that may compete with the objective of trade liberalization, shows that the GATT system allows some form of balance between competing interests and risks.

These examples illustrate how the objective of sustainable development, which may be viewed as a form of common vision of the future of WTO members, has influenced in concrete terms the Appellate Body case law.

\subsection{The Limits of an Evolution of Case Law Based on a Common Vision of the Future}

Even though the objective of sustainable development mentioned in the WTO Agreement Preamble has influenced the Appellate Body case law, a reference to such objective only gives the treaty interpreter a very general indication of the common vision of the future that should be achieved. The principle of sustainable development remains vague and may not provide an answer to all the specific questions that arise in the search for a risk/risk trade-off. Indeed, making a compromise between the different risks and interests at stake indirectly affects various underlying issues, such as what risks are relevant, whose risks eventually count, which risks may be given priority, and so on.

An interesting example is that of possible climate-related trade measures. Even though no such measures have been adopted to date, both the European Union and the United States have, at some point, considered the idea of imposing taxes on imported products based on the greenhouse gases emitted during their production

59 See, eg, WTO, Korea - Taxes on Alcoholic Beverages (17 February 1999) WT/DS75/AB/R, WT/ DS84/AB/R, para 163; Brazil-Tyres, para 178.

60 See WTO, Korea-Measures Affecting Imports of Fresh, Chilled and Frozen Beef (10 January 2001) WT/DS161/AB/R, WT/DS169/AB/R, para 162.

61 See US-ShrimpH, para 159. 
processes. ${ }^{62}$ If such measures were adopted and contested before the WTO, various competing risks would arise-for example, the risk that the absence of measures to reduce greenhouse gases could lead to catastrophic climate changes; the risk that the prohibition of climate-related trade measures could deprive states of meaningful means to sanction states who do not cooperate in greenhouse gases emissions reductions or do not comply with their international commitments; the risk that a generally applicable tax or import prohibition would jeopardize the functioning of the multilateral trading system and lead to an increasing number of trade disputes, retaliations, and so on; the risk that the lack of financial and technical means of developing countries to implement the required measures could mean that they could either lose access to certain markets or reduce the resources allocated to other political priorities. The question is, which risks would be relevant, and which risks should be given priority?

All these risks exist to a certain extent and could potentially be relevant in the interpretation of international trade rules. Most of them may indeed be related directly or indirectly to the achievement of sustainable development. Taking a decision about the justifiability of a PPM measure inevitably has consequences for the respective importance of the competing risks at hand and for the issue of which risk may eventually prevail. Therefore, in the absence of clear rules about the way such competing interests and risks should be considered and integrated, recommendations of the panels and the Appellate Body on these issues will inevitably tend towards policy making rather than interpretation.

Two main consequences ensue. First, legal certainty may sometimes be elusive, at least as long as there is no confirmed practice in relation to the concrete manner in which risks relating to environmental protection and development should be integrated into trade interests, through an interpretation of trade rules congruent with the objective of sustainable development. Second, the margin of manoeuvre concerning the possible views about the influence that sustainable development should have on the interpretation of trade rules gives rise to the issue of the legitimacy of the panels and the Appellate Body to make interpretations which have a policy-making dimension.

Sensitive issues about how competing risks in relation to environmental protection, trade liberalization, or development, such as those mentioned above in relation to climate-related trade measures, should ideally be addressed through international negotiations between states and rest on solutions derived from consensus. But the international community may not necessarily succeed in achieving effective international cooperation when global environmental issues are at stake. Hence, states may sometimes be willing to use unilateral measures to sanction free riding or non-compliance with international efforts to protect the environment. Where unilateral trade measures are imposed and are contested before the WTO,

62 See, eg, J Bhagwati and PC Mavroidis, 'Is Action against US Exports for Failure to Sign the Kyoto Protocol WTO Legal?' (2007) 6 World Trade Review 299; J Pauwelyn, 'U.S. Federal Climate Policy and Competitiveness Concerns: The Limits and Options of International Trade Law' (2007) Working Paper, Nicolas Institute for Environmental Policy Solutions, Duke University. 
it is in practice the panels and the Appellate Body which will be faced with the task of reviewing, through their examination of the relevant conditions of the GATT, whether the enactment of the contested measure takes appropriate account of the competing risks at stake.

However, under the terms of their mandate, the panels and the Appellate Body are not supposed to 'add or diminish the rights and obligations' provided in the WTO agreements. ${ }^{63}$ In practice though, in particular when rather vague concepts such as those used in Articles III and XX of the GATT have to be applied, the panels and the Appellate Body often actually make law, ${ }^{64}$ since their reports are automatically adopted unless there is a consensus among all WTO members not to do so. ${ }^{65}$ There is in theory the possibility of adopting a formal interpretation of the WTO Agreements through the 'legislative' institutions of the WTO (ie, the Ministerial Conference and the General Council), but this requires a three-quarters majority of the members. ${ }^{66}$ In other words, checks and balances between the 'judicial' and 'legislative' branches of the WTO are very difficult to use in practice. In such circumstances, the role of the panels and the Appellate Body is quite uncomfortable, since they may have no other choice, in the absence of clear rules in the relevant provisions, other than to make recommendations which tend towards law making (or policy making), without having a mandate to do so.

It might seem tempting for the panels and the Appellate Body, in such circumstances, to avoid exposing in a transparent way their opinion about which risks are relevant, whose risks count, and which risks may be given priority. When case law lacks transparency, diverging interpretations may easily be made, which means that the Appellate Body is less likely to be criticized for 'making law'. For instance, while the Appellate Body did state that the function of the conditions of the introductory clause of Article XX of the GATT is to find a 'line of equilibrium' between the substantive obligations of the GATT and the general exceptions, it did not clearly identify the nature and extent of the competing risks and interests at stake in the Shrimp-Turtle case; nor did it explicitly weigh these different risks in its application of the conditions of the chapeau of Article XX of the GATT.

However, it is submitted that a lack of transparency may actually reduce the legitimacy of case law. Indeed, transparency is an important aspect of legitimacy, since it allows a meaningful criticism of the case law. ${ }^{67}$ While the GATT provisions require the search for balanced solutions, in particular through the application of the necessity test ('weighing and balancing test') or the conditions of the chapeau ('line of equilibrium'), transparency could be enhanced if clear risk assessments were conducted. These risk assessments could concern in particular environmental

63 Understanding on Rules and Procedures Governing the Settlement of Disputes, Marrakesh Agreement Establishing the World Trade Organization, Annex 2 (DSU), art 3.2.

64 See AT Guzman, 'Global Governance and the WTO' (2004) 45 Harvard International Law Journal 303, 341-42.

65 See DSU, arts 16(4) and 17(14). $\quad 66$ See WTO Agreement, art IX(2).

67 See, eg, R Howse, 'Adjudicative Legitimacy and Treaty Interpretation in International Trade Law: The Early Years of WTO Jurisprudence' in JHH Weiler (ed), The EU, the WTO, and the NAFTA (OUP 2000) 35, $51 \mathrm{ff}$. 
risks and could allow the evaluation of the intensity of the environmental threat, the importance of the natural resources at stake, the scale and magnitude of pollution or degradation, and thus the urgency of intervention, and so on. As far as the risks for trade and development are concerned, the panels and the Appellate Body could focus on the trade-restrictiveness of the measure, the actual and potential effects of the measure on trade flows, the nature and importance of the trade interests at issue, the importance of the products concerned for the exporting countries concerned, and so on.

In the WTO dispute settlement bodies' analyses of the conditions of Article XX of the GATT, these risk assessments could then serve as objective bases to explain how risk/risk trade-offs are decided, for instance in the context of the examination of the conditions of the chapeau or the necessity test. There have been some evolutions in the case law which tend to go in this direction, in particular the interpretation of the necessity test as a 'weighing and balancing test'. As explained above, this test requires, inter alia, the examination of the importance of the interests and values underlying the measure, which may include the environmental risks concerned, and the analysis of the trade restrictiveness of the measure, which may involve the nature of the trade risks at hand. The necessity analysis could thus include a more detailed-or at least a more transparent-assessment of the risks at stake, which would then be useful in the appraisal of the different conditions of Article XX of the GATT, including the conditions of the introductory clause.

\subsection{Conclusion}

This chapter has shown that a change in the vision of the future underlying an international agreement may result in very concrete evolutions in a legal regime applicable to certain specific issues, without any modification of the actual text of the relevant provisions. In the trade context, this new vision-the achievement of sustainable development-has allowed a better consideration of environmental risks in the context of the GATT and the appraisal of trade-related environmental measures under Article XX of the GATT.

There are, however, limits to the evolution of GATT law based solely on the interpretation of the relevant provisions in the light of a new vision of the future. The vagueness of the terms used in these provisions may justify quite different interpretations, as the evolution of the case law about the concept of 'like product' or the conditions of the chapeau of Article XX of the GATT has shown. Moreover, the objective of sustainable development-which is supposed, in the view of the Appellate Body, to bring 'colour, texture and shading' to the interpretation of these provisions - represents a rather vague concept, which may only provide very general guidance to the treaty interpreter. It cannot provide much guidance as to the concrete and practical solutions needed to integrate the competing risks to the environment, trade liberalization, or the interests of developing countries. As a result, the interpretation of these vague provisions in the light of this rather imprecise objective often tends towards law making. 
Yet, the mandate of the panels and the Appellate Body does not include the possibility of engaging in law making, as they must not 'add or diminish the rights and obligations' of WTO members under the WTO agreements. In such context, the WTO dispute settlement bodies are likely to seek to avoid as much as possible findings which might be perceived as law making. Thus, the contradiction which exists between the need to clarify the existing rules and the absence of mandate to create law represents a limit to the possibility to develop, through case law, clear and coherent rules about the integration of competing risks within the GATT system.

Eventually, the adoption of clear rules about the way the common vision of the future underlying the WTO system should be achieved and how competing risks should be taken into account may require international negotiation and the conclusion of an international agreement between WTO members. They could, for example, agree on more precise rules concerning the kind of environmental risks that may justify a trade-restrictive PPM measure. They could also agree, as in the Agreement on Technical Barriers to Trade, which contains several rules designed to address the specific interests of developing countries, on the manner in which the risks that PPM measures represent for the interests of developing countries should be taken into account.

In the meantime, disputes will continue to be brought before the WTO dispute settlement bodies. The ability of the panels and the Appellate Body to keep finding, on a case-by-case basis, balanced solutions and trade-offs in cases in which competing risks are at stake, will play a crucial role in giving more substance to the vision of the future that the achievement of sustainable development represents. It will also play an important role in the legitimacy of the dispute settlement system and the WTO. 